American point of view, occasionally requires adaptation for English students, e.g., some of the test words in the chapter on apperception. This would be of little consequence were it not that the actual pages of the book are intended to be used in the experiments. In spite of this drawback, however, it will be found extremely useful by anyone in charge of, or wishing to form, an experimental class of the kind indicated.

\section{AVIATION DYNAMICS.}

(I) La Théorie de l'Aviation, son application à l'Aéroplane. By Robert Gaston. Préface de Maurice Farman. Librairie des Sciences aéronautiques. (Paris: F. Louis Vivien.) Price I. 50 francs.

(2) Aëroplanes in Gusts. Soaring Flight and the Stability of Aëroplanes. By S. L. Walkden. Pp. $x v+188$. (London: E. and F. N. Spon, Ltd., I9ı2.) Price $7 s$. $6 d$. net.

I $^{\mathrm{T}}$ $\mathrm{T}$ is remarkable how many books have been written in connection with problems on aviation in which the principles of elementary dynamics have been ignored, misinterpreted, or otherwise misunderstood in a way that no candidate for an intermediate B.Sc. examination would believe to be possible. These two books afford excellent examples of this disregard of elementary principles.

(I) M. Robert Gaston, who has a highly flattering preface from Mr. Maurice Farman, finds that if a body is allowed to fall and then stopped at intervals of one second, its average velocity will be 4.9 metres per second (with $g=9.8 \mathrm{I} \mathrm{m} / \mathrm{s}^{2}$ ). If stopped more frequently its average velocity will be less, until we come to the case when it is being stopped at every instant-i.e. continually supported - when its average velocity is nil. Having definitely proved this, he contradicts himself by saying that to maintain a body in the air an upward velocity of 4.9 metres per second must be imparted, so that if the weight is $W$ kilograms, the rate of working must be $4^{\circ} 9 \mathrm{~W}$ kilogram metres per second. If he had adopted a minute, instead of a second, as unit of time, he would have found that the work required was $4.9 \mathrm{~W} \times 60^{2}$ pilogram metres per minute, or sixty times his estimate; similarly, by taking an hour as unit he would have found a result 3600 times as great as he has estimated. Can anything be more absurd? Yet Maurice Farman congratulates him on the clearness and simplicity of his book!

(2) Mr. Walkden's main theme is based on a complete misunderstanding of the physical significance of the law of composition of accelerations.
He measures the effect of a gust of wind by the accelerations of the air particles relative to the aëroplane, and by compounding this acceleration reversed with gravity he gets what he calls the resultant relative gravity. But the result means nothing at all.

The only effect which a gust of wind can have on an aerroplane is due to the pressures of the air on the surfaces and other parts of the aëroplane. These are in general functions of the relative velocity components of the air rather than the accelerations. The best that Mr. Walkden's method can do is to determine their rates of increase, not their actual values. To solve the problem of the aëroplane in gusts it is necessary, in the first place, to determine the six force and couple components of the air pressures as functions of the six components of relative linear and angular velocity of the aëroplane, and, having done this, to investigate the six equations of motion of the aëroplane under the action of these forces and couples. This book does nothing towards solving this problem, and, on the other hand, the appearance of such books is calculated to deter competent mathematicians and physicists from attacking such problems.

\section{OUR BOOKSHELF.}

Didaktik der Himmelskunde und der Astronomischer Geographie. Verfasst von Dr. Alois Höfler. Pp. xii +414 . (Leipzig and Berlin : B. G. Teubner, I9I3.) Price I2 marks.

THIS is the second volume of a useful series of handbooks which is appearing under the general title of "Didaktische Handbücher für den Realistischen Unterricht an Höheren Schulen," and arranged by Professor A. Höfler of Vienna and Professor F. Poske of Berlin. This volume follows that from the pen of the first named, which dealt with mathematical instruction, and its object, like its predecessor, is to reform the teaching of astronomy and astronomical geography in the schools. The volume is essentially for teachers and displays a graduated series of courses of instruction for students commencing when eleven years old and finishing at eighteen. The book is divided into four stages, each stage arranged to cover two years of the student's training. The author strives at great length to impress on the teacher the importance of leading the students to observe for themselves as much as possible, and to show them simple experiments whenever the opportunity arises.

No pains seem to have been spared to provide the teacher with numerous references to works that may be consulted by him, and to draw his attention to numerous points which are not often sufficiently clearly explained to the youthful student.

While the full course here suggested would be

NO. 2292, VOL. 92] 